\title{
Fathers' Needs and Masculinity Dilemmas in a Neonatal Intensive Care Unit
}

\author{
Noergaard Betty, Johannessen Helle, Fenger-Gron Jesper, Kofoed Poul-Erik, Ammentorp Jette
}

Department of Paediatrics, Lillebaelt Hospital, Denmark

*Corresponding author: Noergaard Betty, Department of Paediatrics, Lillebaelt Hospital, Skovvangen 2-8, 6000 Kolding, Denmark, Tel: +45.76362091; E-mail: Betty.Noergaard@rsyd.dk

Received date: March 14, 2018; Accepted date: December 17, 2018; Published date: December 31, 2018

Citation: Noergaard B, Johannessen H, Fenger-Gron J, Kofoed P, Ammentorp J (2018) Fathers' Needs and Masculinity Dilemmas in a Neonatal Intensive Care Unit. J Intensive Crit Care Vol.4 No.4:17

\section{Commentary}

Parents of infants admitted to the Neonatal Intensive Care Unit (NICU) are experiencing concerns and are afraid of losing their infant [1-3]. So far research has been mainly focused on mothers and mother-child relations and less on the fathers' situation. The evidence shows that encouraging father-child bonding is important for the health and development of the infant [4]. Despite fathers roles in society are changing and they often feel both stressed and helpless when their infants are admitted to NICU [5-7] still most healthcare professionals have focused on infants and mothers [6,8-11] and foremost the mothers are engaged in childcare during the hospitalization [11].

Based on a participatory action research study [12] we found that fathers wanted to be involved and take responsibility in the care of their child. The fathers in our study expressed a dilemma between being with their infants and wives at the hospital, and being at work; and they needed guidance and information about their infants care and treatments directly from the staff. Seen in a theoretical framework of masculinity we found that fathers had to balance between cultural and social norms and expectations of men and fathers, being breadwinners and their wishes to be equal co-parents $[2,12]$.

Our study highlighted different aspects of the needs of fathers e.g. the role of gender in childcare and family-centered care; and different concerns should be highlighted. The first one is that in general, new fathers wish to be involved and to have a close relationship to their children. A close relationship between father and child is more and more becoming a paternal quality, and parents in contemporary Danish society are both likely to take part in the childcare [13-15]. Even though parents have the opportunity to share parental leave, it is however mainly mothers who take maternity leave; only $45 \%$ of fathers use the two-week earmarked paternity leave [16]. This means that although fathers have the right to paternity leave, the traditional expectations and norms still guided how they unfold their role $[17,18]$

Another aspect concerns the (lacking) readiness of healthcare professionals and the health care system for catering for the needs of new fathers and their entire families. A study found that nurses in NICU have a lower self-efficacy score on their ability to meet the needs of fathers than mothers [19] and different barriers to involve fathers in childcare at the NICU are reported; such as the size and health status of the infant and the mothers' and staffs encouragement in involving fathers [20].

Care for hospitalized infants is based on family-centred care [21] and a more father-friendly NICU, is the first step towards a real family-centred care in clinical practice, where the needs of fathers as well as mothers and infants are met. The nursing staff should play a key role in this regard because nurses' attitudes to fathers' role in childcare are important. They should reinforce that fathers are as important to their infants as the mothers. Moreover they should be aware of the traditional and cultural norms and expectation of fathers. Especially, how the individual father can balance between these and his own expectations of being a father.

This study contributes to a better understanding of fathers' needs and their potential of enacting fathering roles when their infants are admitted and how the health care system and the interdisciplinary staff should address the needs of new fathers. By supporting fathers to equally partake in childcare health care professionals contributes to the father-child bonding, which is so important for the health of the infants. When fathers are involved they feel a sense of control and thereby they are more able to support their wives.

\section{References}

1. Fegran L, Helseth S, Fagermoen M (2008) A comparison of mothers' and fathers' experiences of the attachment process in a neonatal intensive care unit. J Clin Nurs 17: 810-816.

2. Noergaard B, Ammentorp J, Fenger-Gron J, Kofoed PE, Johannessen $\mathrm{H}$, et al. (2017) Fathers' Needs and Masculinity Dilemmas in a Neonatal Intensive Care Unit in Denmark. Adv Neonatal Care 17: E13-E22.

3. Noergaard B, Ammentorp J, Garne E, Fenger-Gron J, Kofoed PE, et al. (2018) Fathers' Stress in a Neonatal Intensive Care Unit. Adv Neonatal Care 18: 413-422.

4. Fisher D, Khashue M, Adamab EA, Feeleyc N, Garfield CF, et al. (2018) Fathers in neonatal units: Improving infant health by supporting the baby-father bond and mother-father coparenting. J Neonatal Nurs 24: 306-312.

5. Provenzi L, Santoro E (2015) The lived experience of fathers of preterm infants in the Neonatal Intensive Care Unit: a systematic review of qualitative studies. J Clin Nurs 24(13-14): 1784-1794. 
6. Hynan MT (2005) Supporting Fathers During Stressful Times in the Nursery: An Evidence-Based Review. Newborn and Infant Nursing Reviews 5: 87-92.

7. Walmsley R, Jones $T$ (2016) Are fathers supported by neonatal teams?: An exploration of the literature. J Neonatal Nurs 22: 292-296.

8. Ireland J, Khashu M, Cescutti-Butler L, Teijlingen ERV, Jacqui HT (2016) Experiences of fathers with babies admitted to neonatal care units: A review of the literature. J Neonatal Nurs 22: 171-176.

9. Pohlman S (2009) Fathering premature infants and the technological imperative of the neonatal intensive care unit: an interpretive inquiry. ANS Adv Nurs Sci 32: E1-16.

10. Cleveland LM (2008) Parenting in the neonatal intensive care unit. J Obstet Gynecol Neonatal Nurs 37: 666-691.

11. Feeley N, Waitzer E, Sherrard K, Boisvert L, Zelkowitz P (2013) Fathers' perceptions of the barriers and facilitators to their involvement with their newborn hospitalised in the neonatal intensive care unit. J Clin Nurs 22(3-4): 521-530.

12. Noergaard B, Johannessen H, Fenger-Gron J, Poul-Erik K, Ammentorp J (2016) Participatory Action Research in the Field of Neonatal Intensive Care: Developing an Intervention to Meet the Fathers' Needs. A Case Study. J Public Health Res 5: 744.

13. Reinicke K (2002) Den hele mand - manderollen i forandring. Det Schønbergske Forlag.
14. Mosegaard MIC (2007) "Han var en hård mand den gamle". Farsønrelationen set over tre generationer. Dansk Sociologi 18: 47-68.

15. Reinicke K (2012) Drenge og mænd i krise? Perspektiver og indsatsområder. København: Hans Reitzels Forlag.

16. Danmarks S (2015) Dagpenge ved fødsel. Nyt fra Danmarks Statestik Nr. 140.

17. Nielsen SB, Westerling A (2015) Fathering as a learning process: breaking new ground in familiar territory. In: Eydal GB, Rostgaard T, eds. Fatherhood in the Nordic Welfare States. pp: 187-208.

18. Westerling A (2015) Reflexive fatherhood in everyday life: the case of Denmark. Family Relationships and Societies 4: 209-223.

19. Ammentorp J, Kofoed PE (2010) Coach training can improve the self-efficacy of neonatal nurses. A pilot study. Patient Educ Couns 79: 258-261.

20. Feeley N, Gottlieb L, Zelkowitz P (2007) Mothers and fathers of very low-birthweight infants: similarities and differences in the first year after birth. J Obstet Gynecol Neonatal Nurs 36: 558-567.

21. Shields L, Pratt J (2003) Modern nursing and the modern matron. J Med Biogr 11: 181. 